\title{
THE UNACCEPTED REPUDIATION: A THING STILL WRIT IN WATER?
}

\section{Lauren Brazier*}

\begin{abstract}
This article analyses the recent decision of the Supreme Court in Ingram v Patcroft Properties Ltd concerning the legal effect of an unaccepted repudiation. The issue before the Court was whether, and when, a lease had been successfully cancelled by either party. This involved difficult questions of whether there is a "third choice" in the face of a repudiation, the extent to which a party must be ready and willing to perform if it wishes to cancel a contract, and whether the rules of the common law regarding these issues survived the enactment of the Contractual Remedies Act 1979. The article suggests that the Supreme Court did not adequately address these issues. A failure to pinpoint the precise issue in the case gave rise to a confusing judgment that did not fully address the relevant legal principles and their application under the Act. The article discusses those principles, the theoretical issues concerning their application under the Act, and addresses aspects of the judgment in Ingram v Patcroft Properties Ltd that will make the resolution of future cases more difficult.
\end{abstract}

\section{INTRODUCTION}

Traditionally it was thought that a repudiation by one party to a contract that remained unaccepted by the other party was "a thing writ in water and of no value to anybody; it confers no legal rights of any sort or kind". ${ }^{1}$ The case of Ingram v Patcroft Properties Ltd (Ingram) ${ }^{2}$ provided the Supreme Court with the ideal opportunity to examine the legal implications of an unaccepted repudiation. It will be argued that, while the Court decided the case in favour of the right party, and was broadly correct in concluding that an unaccepted repudiation can have legal effect, its reasoning has left the law in this area in a confused state. This is because of a failure to pinpoint the precise issue in the case, which concerned whether the unaccepted repudiation had the very specific legal

\footnotetext{
* Student in the LLB (Hons) programme at Victoria University of Wellington. I would like to thank Professor David McLauchlan for his helpful comments on this article.

1 Howard v Pickford Tool Co Ltd [1951] 1 KB 417 (CA) at 421 per Asquith LJ.

2 Ingram v Patcroft Properties Ltd [2011] NZSC 49, [2011] 3 NZLR 433 [Ingram (SC)].
} 
effect of absolving the promisee from the need to be ready and willing to perform its part in order to bring an action against the promisor for actual breach.

This article will then examine the relevant common law rules and apply them to the facts of Ingram. Importantly, it will discuss whether the common law rules survive the implementation of the Contractual Remedies Act 1979 (the CRA), a source of much uncertainty. Having concluded that the common law rules survive, the article will address particular issues with the Court's approach in Ingram. In particular, it will conclude that the judgment suffered from a lack of clarity as to the relevant principles and authority, both at common law and under the CRA, due in part to the lack of clarity about the main issue in the case. As a result, the Supreme Court has missed a prime opportunity to clarify the law in this complex area.

\section{INGRAM V PATCROFT PROPERTIES LTD}

\section{A Facts}

The parties entered into a lease agreement in 1996. The lessees, Mr Ingram and Ms Knee, ran a backpackers business on the premises. ${ }^{3}$ There were "ongoing difficulties between the parties" regarding payment of rent. Importantly, cl 26 of the lease entitled the lessor to re-enter the premises if the lessees were in arrears on moneys owing "for the space of fourteen days after the same shall have become due".

On 1 June 2005 rent for that month fell due. Two payments were made in June, one of which discharged moneys owing on the April balance. However, as at 13 June, the lessees still owed a significant amount on the June balance. On the morning of 14 June, one day before the right of reentry was exercisable under $\mathrm{cl} 26$, the lessor (Patcroft) re-entered the premises and purported to terminate the lease. Subsequent correspondence from the lessees informed the lessor that "the reentry had occurred on the 13th day after the rent was due, in clear breach of the lease". However, the lessor maintained its position that the lease was "now defunct". ${ }^{4}$ Over a year later, in response to a letter sent by the lessor demanding over $\$ 1$ million in damages, the lessees sued.

\section{B High Court and Court of Appeal Decisions}

\section{High Court}

In the High Court the lessees claimed substantial damages for the loss of their business, as a result of the wrongful re-entry. The lessor, maintaining the lease was validly terminated, counterclaimed for "significant sums"5 it said remained owing by the lessees. The key issues

3 Mr Ingram and Ms Knee also assigned part of the premises to KIP Investments Ltd, making them a direct lessee from Patcroft Properties Ltd. However, this article will not deal with the claim of KIP Investments Ltd insofar as it differs from that of Mr Ingram and Ms Knee.

4 Ingram (SC), above n 2, at [16].

5 Ingram v Patcroft Properties Ltd (2009) 10 NZCPR 426 (HC) at [8] [Ingram (HC)]. 
addressed were first, whether the re-entry was unlawful, and second, if it was, whether this precluded the lessor from "claiming to have cancelled on or after 15 June on the ground of the lessees' continuing failure to pay the balance of the June rent". 6

Allan J held the re-entry on 14 June was unlawful as it contravened cl 26. His Honour also held that the expiration of time between the re-entry on 14 June and 15 June, when the lessor would have been entitled to re-enter under $\mathrm{cl} 26$, did not give rise to a "fresh, additional, right to terminate the lease for non-payment of rent", ${ }^{7}$ as counsel for the lessor had argued. Further, his Honour declined counsel for the lessor's invitation to draw the inference that the lessees did not have the funds to pay the arrears.

\section{Court of Appeal}

The lessor appealed. The issues before the Court of Appeal were identical to those before Allan $\mathrm{J}^{8}$ A majority allowed the appeal. O'Regan and Ronald Young JJ considered that, while the re-entry on 14 June was unlawful, the lessees had not made an election to cancel the contract on 14 June. This meant on 15 June "the contract remained alive" 9 and the lessor was entitled to cancel under cl 26 "because the rent by then had been outstanding for 14 days". The lessor's "continual refusal to allow the tenants access to the premises was a re-entry"10 which "lawfully brought the lease to an end". ${ }^{11}$

Priestley $\mathbf{J}$ dissented. First, while his Honour agreed that the re-entry was unlawful, he considered it was "artificial and unreal to endeavour to construct a situation"12 where either party had cancelled. Second, he thought that ss 7 and 8 of the CRA envisaged a connection between one party's breach and the other's cancellation. In this case, there was no evidence of a connection: "[r]ather, the appellant [had] maintained its own repudiation of the contract." 13 Third, Priestley J expressed the tentative view that a party who wished to cancel a contract at common law had to be ready and willing to perform that contract. His Honour stated that the purpose of this rule was "to

6 Ingram (SC), above n 2, at [18]. Other issues were also addressed but they are not relevant to the present discussion.

7 Ingram $(H C)$, above $\mathrm{n}$ 5, at [56].

8 Other issues were also dealt with on appeal but they are not essential to the present discussion.

9 Patcroft Properties Ltd v Ingram [2010] NZCA 275, [2010] 3 NZLR 681 at [54].

10 At [54].

11 At [55].

12 At [70].

13 At [87]. 
ensure a party did not benefit from its own wrong". ${ }^{14}$ In this case, if successful, the lessor would have benefitted from its own wrong, as its "cancellation" had "effectively precluded"15 the lessees from paying the rent. His Honour noted the law in this area was "obscure"16 and that there was uncertainty surrounding whether this requirement had survived the introduction of the CRA. ${ }^{17}$

\section{The Supreme Court Decision}

The lessees appealed. The question was: "in circumstances in which the respondent's re-entry into the premises on 14 June 2005 was invalid, whether, and when, either of the parties thereafter validly terminated the lease". 18

\section{Arguments}

The lessees argued that the lessor had not validly cancelled on 15 June. Counsel relied on Hirst $v$ Vousden (Hirst $)^{19}$ as authority for the proposition that the lessees were under no obligation to pay rent once the lessor repudiated. Thus, the lessor could not turn around the following day and terminate for non-payment of rent. ${ }^{20}$ As further support for the proposition that "a party cannot avoid the consequences of its own breach by cancelling on the basis of the other party's subsequent breach," 21 the lessees invoked the "concept that a party must be ready, willing and able to [perform] a contract before it can cancel".22

The lessor argued that the lessee was the party in breach from 1 June to 14 June and should not be able to take advantage of its own breach. By remaining in possession the lessor exercised the right of re-entry under $\mathrm{cl} 26$ and cancelled the contract. In response, the lessees argued that even if they were in breach at 1 June, that breach "was not a repudiatory breach until 15 June". 23

14 At [89] in reliance on Glazebrook $\mathrm{J}$ in Noble Investments $v$ Keenan [2006] NZAR 594 (CA) [Noble Investments Ltd].

15 At [89].

16 At [89].

17 At [89].

$18 \operatorname{Ingram}(S C)$, above $\mathrm{n} 2$, at 435.

19 Hirst $v$ Vousden (2004) 6 NZCPR 135 (PC) [Hirst v Vousden (PC)]; Hirst v Vousden CA25/02, 19 August 2002 [Hirst $v$ Vousden (CA)].

20 Ingram v Patcroft Properties Ltd [2011] NZSC Trans 8 at 20; Ingram (SC), above n 2 at 436.

21 Ingram (SC), above n 2, at 436.

22 Ingram v Patcroft Properties Ltd, above n 20, at 25.

23 Ingram (SC), above n 2, at 437. 


\section{Decision}

In a unanimous judgment delivered by Blanchard J, the Supreme Court allowed the appeal. The reasons centred on the Court of Appeal and Privy Council decisions in Hirst. That case concerned an oral agreement to lease a takeaway bar and accommodation business. The terms were unclear, but the courts held there was a lease for an initial period of one year, with the lessees (the Vousdens) having an option at the end of this period to "a lease for three years (with two rights of renewal of three years each)". ${ }^{24}$ Difficulties ensued when the condition of the takeaway bar meant it had to be closed for over eight months. Further, the lessees were unable to rent out five cabins, as they required improvements, and the lessors (the Hirsts) then deliberately refrained from connecting them to power and water. All the while the lessees paid full rent on the understanding "there would be an appropriate adjustment at a later time". ${ }^{25}$

After the initial year expired, the lessors "contended that there was no continuing lease arrangement". ${ }^{26}$ The lessees "remained in occupation and continued to operate the takeaway bar".27 They also stopped paying rent while negotiations occurred, due to the lessors' refusal to extend the tenancy and the difficulties during the first year. When negotiations failed, the lessees were evicted and they sued the lessors for breach of the lease.

The issue before their Lordships was "whether the Vousdens' non-payment of rent, after April 2000, entitled the Hirsts to ... re-enter the premises". ${ }^{28}$ Their Lordships affirmed the reasoning of the Court of Appeal that: ${ }^{29}$

The Hirsts were disentitled from taking the point against the Vousdens because they themselves were denying the existence of any continuing contract and thereby repudiating it. How can it be said that lessees are obliged to keep making rental payments pursuant to a contract ... when the lessors are refusing to acknowledge the existence of the lease contract? And how can a purported cancellation of the lease on that ground be valid.

Thus the termination was unlawful and the lessees were entitled to damages.

The Supreme Court considered that Ingram was a materially similar case to Hirst, and therefore that it should be decided in the same way. ${ }^{30}$ The Court concluded on the basis of Hirst that the: ${ }^{31}$

24 Hirst $v$ Vousden (CA), above n 19, at [13].

25 At [15].

26 At [18].

27 At [18].

28 Hirst $v$ Vousden $(P C)$, above n 19, at [15].

29 Hirst $v$ Vousden (CA), above n 19, at [16]; Hirst v Vousden (PC), above n 19, at [15]-[16].

30 Ingram (SC), above n 2, at [27]-[30]. 
... ongoing repudiation by the lessor prevented it from claiming a right to cancel for non-payment of rent. Its purported cancellation was entirely inconsistent with its stance that the lease no longer existed (as from 14 June).

Further the "non-payment of rent was justified by the re-entry". ${ }^{32}$ Importantly their Honours also stated that Allan J in the High Court accepted Mr Ingram's evidence that he could and would have paid the rent on 14 June if the lease had not been terminated. ${ }^{33}$ They also noted Mr Ingram was not effectively challenged on this evidence. ${ }^{34}$

The Court proceeded to reconcile this reasoning with "the well-known dictum of Asquith LJ that an unaccepted repudiation is a 'thing writ in water and of no value to anybody'". ${ }^{35}$ Their Honours noted J W Carter's view that an unaccepted repudiation can have legal consequences. ${ }^{36}$ Notably, it may "prevent the repudiating party ... from exercising rights under the contract", 37 and "absolve a promisee from the consequences which would otherwise attach to a failure" to perform. ${ }^{38}$ Three Australian State level cases were offered in support of Carter's view. ${ }^{39}$

The Court then discussed how cases on anticipatory breach support this view, "although they have tended to be expressed in terms of waiver rather than estoppel". 40 Their Honours cited Dawson and McLauchlan's ${ }^{41}$ discussion in their book The Contractual Remedies Act 1979 of common law cases holding that "an unretracted repudiation was an intimation that it was useless for the innocent party to go to the trouble of incurring unnecessary expenditure in making preparations to perform". ${ }^{42}$ The Court recognised that this meant a party could put a contract into suit without having to demonstrate its readiness and willingness to perform, ${ }^{43}$ and went on to examine the

31 At [29].

32 At [30].

33 At [12], referring to Ingram (HC), above n 5, at [76].

34 At [30].

35 At [31].

36 At [31].

37 At [31].

38 At [31].

39 At [31].

40 At [37].

41 Francis Dawson and David W McLauchlan The Contractual Remedies Act 1979 (Sweet and Maxwell, Auckland, 1981).

$42 \operatorname{Ingram}(S C)$, above $\mathrm{n}$ 2, at [37].

43 At [37]. 
discussion by Dawson and McLauchlan regarding whether this position remains under the CRA. ${ }^{44}$ The Supreme Court supported Dawson and McLauchlan's view that, although s 7(1) states the section shall have effect in place of the common law, "this does not affect 'the waiver cases"'. ${ }^{45}$ According to the Court, s 7(1) does not apply in the waiver cases because the other party's nonperformance is excused, and thus there is no breach for the repudiating party to take advantage of under s 7.46 Their Honours deemed this "a sensible construction of s 7(1) which aligns it with the general principle" that if one party intimates to the other that performance is unnecessary, it cannot then take advantage of subsequent non-performance. They considered this to be the "result of an estoppel". 47

Thus, it was concluded that the "common law rule requiring that a cancelling party be ready and willing to perform the contract", 48 has survived the passing of the CRA. However, based on the judgment of Glazebrook $\mathrm{J}$ for the Court of Appeal in Noble Investments Ltd v Keenan (Noble Investments), ${ }^{49}$ the Court stated that this rule only applied if the cancelling party would "benefit from its own wrong". ${ }^{50}$ For example, if the cancelling party sought "to deprive the other party of the benefit of the contract in circumstances where the other party's breach is a direct result of breach committed by the [cancelling party]". 51

\section{THE ISSUE}

Ingram thus concerned a complex area of law regarding the effect of an unaccepted repudiation. Carter considers that the law in this area is "little more than a series of contradictions". 52 Traditionally, the courts have viewed promisees as having two options when a repudiation occurs. ${ }^{53}$ They may elect either to terminate the contract or to affirm the contract and continue with performance. ${ }^{54}$ However some courts, despite judicial statements such as Asquith LJ's, have

\footnotetext{
44 At [38].

45 At [38].

46 At [38].

47 At [39].

48 Ingram (SC), above $\mathrm{n}$ 2, at [40].

49 Noble Investments Ltd, above n 14.

50 At $[40]$.

51 At [40].

52 JW Carter "Discharge as the Basis for Termination for Breach of Contract" (2012) 128 LQR 283 at 297.

53 JW Carter Breach of Contract (3rd ed, LexisNexis, Chatswood (NSW), 2010) at [7-50]. This is known as the doctrine of election.

54 Carter, above n 53, at [7-50].
} 
embraced the possibility of a third choice. ${ }^{55}$ These cases hold that the effect of an unaccepted repudiation is "to absolve a promisee from the consequences of a failure to perform". ${ }^{56}$

In order to examine properly the effect of an unaccepted repudiation a clear understanding of the terminology involved is required. The difficulties in this area are compounded by the failure to distinguish between repudiation and breach, ${ }^{57}$ and this is further compounded by the use of inexact terminology. Ingram itself provides a prime example of these difficulties.

A repudiation occurs where a party "[evinces] an intention by words, or by conduct, no longer to be bound by the contract". ${ }^{58}$ A repudiating party is in essence saying "I will not perform my promise". ${ }^{59}$ Breach, however, does not require any "finding of an intention not to perform". ${ }^{60}$ Instead, it is concerned merely with a party having failed to perform his or her promise by the due date. ${ }^{61}$ This party cannot be in breach unless the other is ready and willing to perform the contract. ${ }^{62}$ A repudiation that occurs in the course of performance will also amount to an actual breach if the repudiating party fails to perform as a result. ${ }^{63}$

Francis Dawson ${ }^{64}$ has argued that it "was a failure to mark the elementary distinction between actual breach and repudiation which caused difficulty in Chatfield v Jones". 65 As he stated in the Law Commission's Contract Statutes Review, "the key to unravelling this difficult area is to distinguish between repudiation ... and breach." ${ }^{66}$ In cases involving an unaccepted repudiation the

55 Carter, above n 52, at 298.

56 At 298 .

57 Francis Dawson "Contract" [1991] NZ Recent Law Review 19 at 23.

58 Dawson and McLauchlan, above n 41, at 59.

59 Francis Dawson "Contractual Remedies Act 1979 Commentary" in Law Commission Contract Statutes Review (NZLC R25, 1993) 101 at 107.

60 Dawson and McLauchlan, above n 41, at 59.

61 Dawson, above n 59, at 107.

62 At 105.

63 Dawson and McLauchlan, above n 41, at 58.

64 Dawson, above n 57, at 23.

65 Chatfield $v$ Jones [1990] 3 NZLR 285 (CA). Chatfield $v$ Jones concerned an agreement for the sale and purchase of shares. At the time for performance the purchasers failed to settle, maintaining they were not bound to do so. The vendors sought specific performance, or damages in the alternative. The vendors then re-sold the shares without communicating to the purchasers that they were cancelling. The case was "argued in terms of repudiation, affirmation and election to cancel," and Dawson notes that it "does not make for easy reading." See Dawson, above n 57, for a detailed analysis of the case.

66 Dawson, above n 59, at 107. 
innocent party is "not basing a claim on wrongful repudiation", despite one being present, "but on actual breach by the other contracting party". ${ }^{67}$ This is because the concern in such cases is that the other contracting party has not actually performed on the due date, not that it has said it will not perform. ${ }^{68}$ Therefore, the ${ }^{69}$

... essence of the problem in this area is whether, in the case of an actual breach of contract, an

unretracted repudiation should dispense with an innocent promisee's obligation to show readiness and

willingness on the date for performance ... [to bring an action for actual breach].

If an unretracted repudiation does dispense with this obligation the promisee is essentially absolved from the consequences of a failure to perform, thus providing the third choice. Assessing whether an unaccepted repudiation has this effect will involve a detailed examination of the common law rules regarding readiness and willingness, and whether these rules have survived the CRA.

The judgment in Ingram suffered from not identifying this as the precise issue. Two factors contributed to the specific issue not being identified. First, loose terminology was used when describing the lessees' claim. Second, too great an emphasis was placed on the lessor's claim.

\section{A Loose Terminology}

Although the Court appears to have identified the lessees' action as being founded on actual breach, their Honours did not do so explicitly. They merely stated that the conduct of the lessor gave rise to "a right of cancellation on the part of the lessees under s 7(4)(b) of the Contractual Remedies Act"70 (which deals with cancellation for actual breach.) However, it is their description of the lessor's conduct surrounding this that gives rise to the difficulty regarding the issue. They (understandably) made reference to the lessor's "repudiatory stance"71 and "repudiation". ${ }^{72}$ In light of these references, and the fact s 7(2) of the CRA provides for cancellation for repudiation, the judgment would have been clearer if the Court had explicitly stated that the action was founded on actual breach and explained how this related to the problem of unaccepted repudiations.

67 At 107.

68 This is different to claims based on repudiation (or anticipatory breach) where the concern is that the other party has said it will not perform. There, the issue of whether the promisee's obligation to show readiness and willingness at the date of performance should be dispensed with does not arise. This is because the date of performance has not yet arrived. The promisee need only show that it was ready and willing at the time of the repudiation.

69 Dawson, above n 59, at 107.

70 Ingram (SC), above n 2, at [24].

71 At [24].

72 At [25]. 
Their Honours' description of the lessor's conduct as a "repudiatory breach"73 compounded this problem by conflating the concepts of repudiation and breach. Dawson and McLauchlan describe the increasing use of the term "repudiatory breach" "to denote any breach entitling the innocent party to treat himself as discharged"74 as problematic. Carter in his Breach of Contract takes the same position, stating that the term blurs the "fundamental"75 distinction between repudiation and breach. ${ }^{76}$ Using this term thus adds to the confusion regarding the basis of the lessees' claim.

In addition, the Court stated that "as long as the lessor's repudiatory stance was unchanged it would be a continuing breach capable of acceptance and cancellation by the lessees under that Act." 77 This description, whilst again getting close to explicitly identifying that the lessees' action was founded on actual breach, appears to also conflate the concepts of repudiation and breach. Although it is true to say that the repudiation amounted to a breach, ${ }^{78}$ traditionally under the doctrine of election one would speak of accepting a repudiation, not a breach. ${ }^{79}$

\section{B Emphasis on Lessor's Claim}

The Court also had to deal with whether the lessor was able to cancel the contract on June 15 despite its unretracted repudiation. This issue caused significant confusion in the Court of Appeal, and thus the Supreme Court framed their reasoning around it. They stated, in summary, that the issue was whether "subject to any disqualifying effect of the lessor's continuing repudiation, it was open to the lessor to bring the lease to an end" ${ }^{80}$ It is suggested that this is a mischaracterisation of the true issue in the case. The lessor's claim can be dealt with simply using the principles discussed below. The main issue, which the case should have been framed around, was whether the unaccepted repudiation absolved the lessees of their obligation to be ready and willing to perform,

73 At [24] and [29].

74 Dawson and McLauchlan, above n 41, at 58 and 59.

75 Carter, above n 53, at [7-07].

76 At [7-07].

77 Ingram $(S C)$, above $\mathrm{n} 2$, at [24].

78 See Part V below.

79 See Dawson and McLauchlan, above n 41, at 72 where the authors discuss "unaccepted" repudiations. See also Dawson and McLauchlan, above n 41, at 58 where the authors discuss the doctrine of election. The Supreme Court makes this point more clearly at [2]. However, further confusing matters, their Honours, in describing the reasoning of the High Court, intimated that the lessees' claim was based on damages for repudiation, not breach. Discussing Allan J's conclusion that the issue of proceedings ultimately accepted the lessor's repudiation, they referred to the lessees "seeking damages for the lessor's repudiation". Whilst this was the language employed by Allan J, the Supreme Court could have been true to Allan J's reasoning by simply discussing how the proceedings ultimately accepted the lessor's repudiation.

80 Ingram (SC), above n 2, at [26]. 
thus enabling them to bring an action for actual breach against the lessor. Put more simply, the true question is whether the conduct of the lessor amounted to a breach of contract.

\section{COMMON LAW}

In order to discuss the true issue in Ingram a detailed exposition of the common law rules regarding discharge for breach is required. The common law position is well set out in the High Court of Australia's decision in Foran $v$ Wight (Foran). ${ }^{81}$ That case concerned the effect of a repudiation by the vendors on the obligations of the purchasers under an agreement for sale and purchase of land. The contract stipulated settlement was to take place "on or before June 22, 1983", time being of the essence. On 20 June the vendors' solicitor informed the purchasers that the vendors would be unable to settle on that date. ${ }^{82}$ On 24 June the purchasers rescinded the contract based on the vendors' actual breach in not completing on 22 June. ${ }^{83}$ They later sought the return of their $\$ 7,500$ deposit. ${ }^{84}$ Brennan $\mathrm{J}$ described the question in the case as "whether the failure by the vendors to complete on [22 June] was a breach of contract." 85

Questions of readiness and willingness to perform are inextricably woven into this issue. Because at common law one party (A) was not in breach unless the other party (B) was ready and willing to perform its part, ${ }^{86}$ an examination of the extent to which the need for party B to be ready and willing to perform survives a repudiation is essential to the question of whether an action could be maintained for breach of contract.

At common law a "contracting party was given an election on a wrongful repudiation: he could choose to terminate the contract immediately or he could wait until the date for performance to bring his action". ${ }^{87}$ The High Court in Foran made it clear that: ${ }^{88}$

81 Foran v Wight (1989) 88 ALR 413 (HCA) [Foran].

82 This was because the right of way the vendors were required to give under one of the special conditions of the contract was not yet registered.

83 At 433 per Brennan J.

84 At 433 per Brennan J.

85 At 434. This was essentially the exact issue in Ingram.

86 Dawson, above n 59, at 105; Foran, above n 81, at 439. It is important to note two things at this point. First, readiness and willingness also includes the ability to perform. Second, being in breach in a minor respect will not mean a party is not ready and willing to perform. See Almond Investors Ltd v Kualitree Nursery Pty Ltd [2011] NSWCA 198. Clearly the latter was not at issue in Ingram.

87 Dawson and McLauchlan, above n 41, at 75.

88 Foran, above n 81, at 460 per Dawson J. 
In any action for breach of contract, the readiness and willingness of [party B] to perform those mutual obligations remaining to be performed on his part under the contract is a condition precedent to his right to recover.

In other words, readiness and willingness is a "part of his cause of action". ${ }^{89}$ Thus at common law a party who chose to wait until the date of performance "had to remain ready and willing to perform his part". ${ }^{90}$ Unsurprisingly, this led to some unjust results and "the courts devised a number of techniques to circumvent" them. ${ }^{91}$ One technique invoked "an old line of cases on waiver of conditions precedent". 92 These cases held that: ${ }^{93}$

... an unretracted repudiation was an intimation that it was useless for the innocent party to go to the trouble of incurring unnecessary expenditure in making preparations to perform. The result was that even though a contracting party had not elected to terminate a contract for wrongful ... repudiation, he was able to sue for actual breach on the date of performance without having to show that he was ready and willing to perform his part.

Thus a repudiation by party A dispenses party B from "being ready and willing at the time of performance". ${ }^{94}$ However, readiness and willingness is still relevant to the inquiry. ${ }^{95} \mathrm{~B}$ must have been ready, willing and able to perform at the time of the repudiation. ${ }^{96}$ If $\mathrm{B}$ was disposed not to perform, or incapacitated from doing so when A repudiated, this "denies the character of breach to a failure to perform" by A. ${ }^{97}$ Therefore, the relevant assessment is "readiness and willingness up to the time when the intimation is given and it relates to B's then disposition and capacity to perform

89 At 460 per Dawson J.

90 Dawson and McLauchlan, above n 41, at 75 and 76.

91 At 75 and 76

92 At 77.

93 At 77.

94 Foran, above n 81, at 442 per Brennan J.

95 See generally Francis Dawson "Waiver of Conditions Precedent on a Repudiation" (1980) 96 LQR 239.

96 Foran, above n 81, at 442 per Brennan J.

97 At 442 per Brennan J. Where A repudiates, and B is unwilling or unable to perform, while A's repudiation may be justified, this does not necessarily mean that A can sue B. A can only sue B for damages if A can show that A would have been ready and willing to perform but for B's lack of readiness and willingness. Alternatively, if neither party is ready and willing to perform but for the repudiation or non-performance of the other, both parties will be discharged, but neither will be able to sue. This is the usual position where A seeks to provide a subsequent justification for its repudiation, because it is unlikely A will be able to satisfy the but for test outlined when repudiating on a stand-alone basis and later seeking to justify it to avoid liability. This seems a sensible approach: a party can avoid liability by providing a subsequent justification for its repudiation, but cannot sue the other party for damages on the basis of that justification. See Dawson and McLauchlan, above n 41, at 81-85. 
his obligation when the time for performance arrives". ${ }^{98}$ If this is satisfied, A is in breach, despite B not being ready, willing and able to perform at the time for performance.

The extent to which B must be ready and willing to perform depends on what B is claiming. The Court in Foran stated that if B seeks damages the test is whether but for A's repudiation B would have been able to perform at the time stipulated. ${ }^{99}$ Brennan $\mathrm{J}$ stated that: ${ }^{100}$

Had the purchasers' sought to recover substantial damages from the vendors for the vendors' failure to complete on 22 June, the purchasers' inability to prove that they would have been able to pay the price on that day would have been fatal to the claim.

However, the purchasers in Foran were not claiming damages - they merely sought the return of their deposit. In this situation the appropriate test was whether "the purchasers were already "substantially incapable" of raising the needed finance to tender on 22 June". ${ }^{101}$ As the purchasers were not substantially incapable of performing, they were held to have been ready and willing up until the time of the repudiation, and were entitled to recover their deposit. ${ }^{102}$ The Court in Foran expressly acknowledged this as the third choice. ${ }^{103}$

It is also important to note that at common law "a party could treat itself as discharged on the ground of the other party's failure to perform, notwithstanding that it had failed to perform its part". 104 Thus, where both contracting parties were not ready and willing to perform "both parties were discharged but neither could sue". ${ }^{105}$ It was only necessary to be ready and willing to perform in order to put the contract into suit. ${ }^{106}$ The circumstances in which one must be ready and willing to perform in order to put the contract into suit are qualified by the principles discussed.

98 At 442 per Brennan J.

99 At 445 per Brennan J.

100 At 445.

101 At 445 per Brennan J.

102 At 446 per Brennan J.

103 At 438 per Brennan J; at 465 per Gaudron J.

104 Dawson, above n 59, at 105.

105 Dawson and McLauchlan, above n 41, at 82; See also Dawson, above n 59, at 104. This may be, for example, where both parties have repudiated their obligations. As neither party is ready and willing to perform, neither can enforce the contract. Their repudiations are justified by the lack of readiness and willingness on the part of the other party. Therefore neither of the repudiations is wrongful. Both parties are discharged, but neither can sue.

106 For example, to take an action for damages based on breach of the contract, unless, of course, the need to be ready and willing to perform was dispensed with due to an unretracted repudiation. 
This position developed from the common law pleading rules from the $1700 \mathrm{~s}^{107}$ "established in such cases as Kingston v Preston and Boone v Eyre". ${ }^{108}$ Originally at common law both sides could put a contract into suit regardless of whether they were ready and willing to perform. ${ }^{109}$ This is because the promises made by each party were considered independent. ${ }^{110}$ However, around 1770 it became accepted that promises were mutual, dependent, or conditional on the other party's performance. 111 "Technically this was achieved by implying a condition that the promisee must show readiness and willingness to perform."112 Not being ready and willing to perform became known as a breach of a condition precedent. ${ }^{113}$ This position: ${ }^{114}$

...remains as the basic infrastructure of the common law approach to discharge by breach, as is made clear by ... Foran ... which considered the problem of the unaccepted repudiation.

The approach taken by the majority of the High Court in Foran has been criticised by Carter. ${ }^{115}$ $\mathrm{He}$ argues that the purchasers' readiness and willingness was "irrelevant to their entitlement to terminate the contract". ${ }^{116}$ He states that the Court: ${ }^{117}$

... may have been rather too heavily influenced by cases decided on the old system of pleading under which a plaintiff was required to aver performance or readiness and willingness to perform. In those cases what was at issue was the right of the plaintiff to enforce the contract, not the right to terminate the contract for repudiation of obligation. A person who calls upon a promisor to perform must necessarily be in a position to perform. However, since the purchasers in Foran did not seek damages but merely claimed to have validly terminated the contract, they did not call on the vendors to perform.

It is suggested that this criticism is unfounded. At common law where the promisee "could not show the appropriate readiness and willingness", 118 the repudiating party "could not be held to the

107 Dawson, above n 59, at 105.

108 Dawson and McLauchlan, above n 41, at 82.

109 Dawson, above n 59, at 105.

110 DW Greig and JLR Davis The Law of Contract (The Law Book Company Ltd, Sydney, 1987) at 1200.

111 Greig and Davis, above n 110, at 1201; Dawson, above n 59, at 105.

112 Dawson, above n 59, at 105.

113 At 105.

114 At 105 .

115 Carter, above n 53.

116 Carter, above n 53, at [7-65].

117 At [7-65].

118 Dawson and McLauchlan, above n 41, at 82. 
contract. The "repudiation" was justified". ${ }^{119}$ Essentially, in Foran, by asking if the purchasers were "substantially incapable"120 of performing, the Court was assessing whether they were wholly and finally disabled from performing. ${ }^{121}$ If this had been the case, the repudiation by the vendors would have been justified and the vendors may have been able to retain the deposit. ${ }^{122}$ Claiming the deposit involved an element of putting the contract in suit, making some assessment of readiness and willingness essential to determine if there was an actual breach warranting the remedy sought.

It is important also to note that some members of the High Court advanced estoppel as the doctrinal basis for their decisions. ${ }^{123}$ This article will not address estoppel. Suffice it to say that the Court in Foran recognised they were extending the doctrine of estoppel, ${ }^{124}$ and, according to Carter "there is no need to invoke estoppel. Indeed, the less that is said about estoppel the better." ${ }^{125}$ Thus, waiver of conditions precedent in an action for actual breach is the appropriate vehicle for deciding cases concerning unaccepted repudiations.

\section{APPLICATION TO INGRAM}

On application of the common law principles to the facts of Ingram it becomes clear that the lessor could not cancel for breach or sustain an action against the lessees for damages. Given that

119 At 82 .

120 Foran, above $\mathrm{n} 81$, at 445 per Brennan J.

121 Foran, above n 81, at 441 per Brennan J. When discussing the test of substantial incapacity his Honour states: "Lord Sumner's phrase - "wholly and finally disabled" - is too demanding a test of incapacity to accord with reasonable commercial practice but it is indicative of the range which the test of substantiality connotes."

122 If the purchasers had been wholly and finally disabled from performing, neither party is ready and willing to perform, therefore both will be discharged, and neither can sue. That is because, on the facts of Foran, it is unlikely the vendors would have been able to show that they would have been ready and willing but for the purchasers non-performance, due to their non-registration of the right of way. The outcome here is subject to a possible claim in unjust enrichment for restitution by the purchasers against the vendors for the deposit. However, if the facts were varied, such that the purchasers' were wholly and finally disabled, but the vendors could show that but for this they would have been ready and willing to perform, then the vendors may have had a claim for damages. It would be a different story altogether if the facts were that the vendors repudiated because they no longer wanted to sell, and unbeknownst to the vendors, the purchasers were wholly and finally disabled from performing. Here, the vendor could not realistically show that but for the purchasers' non-performance or repudiation that they would have been able to perform. Neither party is ready and willing to perform. Both will be discharged, and neither can sue. See generally Dawson and McLauchlan, above n 41, at 81-85.

123 JW Carter "Foran v Wight" (1990) 3 JCL 70 at 76.

124 Foran, above n 81, at 430 per Mason CJ, at 448 per Deane J, at 459 per Dawson J. But see at 464 per Gaudron $\mathbf{J}$ where her Honour, while recognising the doctrine of estoppel would be extended if applied to this case, states "a consideration of estoppel is unnecessary in the present case."

125 Carter, above n 52, at 301. 
the lessor was not ready and willing to perform on the 14th, the lessees were not in breach when they did not pay. There was nothing to justify the conduct of the lessor, or to absolve it from the requirement that it be ready and willing to perform in order to put the contract into suit in this case. Thus, the issue was whether the lessees could sustain an action for actual breach against the lessor, despite not being ready and willing perform on the 14th. The answer is that the unretracted repudiation of the lessor waived the condition precedent requiring the lessees to be ready and willing to perform to bring an action for actual breach.

Of course, the repudiation did not waive it entirely. ${ }^{126}$ The lessees still had to prove that but for the repudiation they would have been ready and willing to perform at the time for performance, in order to claim damages. ${ }^{127}$ There is a distinction to be drawn, as indicated in Foran, between situations where all that can be shown is that the promisee is not substantially incapable of performing, and situations where it can be shown that but for the repudiation the promisee would have performed. Only promisees who can prove the latter are entitled to damages.

Allan $\mathrm{J}$ in the High Court declined to draw the inference, put forward by the lessor, that the lessees did not have the funds to pay the arrears, because there was unchallenged evidence that $\mathrm{Mr}$ Ingram intended to pay and his sister "could have provided funds at a few hours' notice, as she had done for him in the past". ${ }^{128}$ Thus, Allan J essentially held, as a finding of fact, that the lessees were not substantially incapable of performing at the time of the repudiation. There was the possibility that they still may have performed.

126 See Dawson, above n 95.

127 Unlike the old common law pleading rules, compliance with conditions precedent is now averred generally or implied in England and Australia, requiring the defendant to put non-compliance with a condition precedent in issue. While the current High Court Rules do not specifically address this point, it is suggested that the courts would follow a similar approach to their English and Australian counterparts. See Dawson, above n 59, at 105. In Ingram the lessor intimated in the High Court that the lessees simply did not have the funds available to pay the rent, thus putting the lessees' compliance with the condition precedent that they be ready and willing to perform at issue. The onus is then on the lessees, in order to succeed in their claim, to show their ability to perform. This burden on the plaintiffs is probative, but is relatively easily discharged by limited evidence where the defendant does not adduce evidence to the contrary. This position is best illustrated by Jefferson $v$ Paskell [1916] 1 KB 57 (CA). In that case the plaintiff sought damages from the defendant for breach of his promise to marry her. He argued he was justified in refusing as, due to illness, she was not ready and willing to perform. The Court of Appeal held the onus was on the plaintiff to prove her readiness and willingness. In particular Phillimore LJ stated the trial Judge was wrong to place the burden of proving the plaintiff was unfit on the defendant. This is confirmed in Henthorn and Taylor $v$ Central Electricity Generating Board [1980] IRLR 361 (CA), Abdullah Bey Chedid v Tenenbaum PC AP47/1932, 9 October 1933 at 10-11, and Peter Turnbull and Co Pty Ltd $v$ Mundus Trading Co (Australasia) Pty Ltd (1954) 90 CLR 235 (HCA) at [5] per Kitto J. Peter Turnbull was the leading authority pre-Foran. Dawson and McLauchlan, writing prior to Foran, referred to Peter Turnbull as the "best modern illustration of the waiver line of cases."

128 Ingram (SC), above n 2, at [12]. 
The Supreme Court considered Allan J's refusal to draw the suggested inference meant there was a finding of fact that but for the repudiation the lessees would have paid. ${ }^{129}$ However, given the crucial distinction between being not substantially incapable and being ready and willing but for the repudiation, it is suggested that the Supreme Court in fact went a step further than Allan J, and that the assumption that these two situations are synonymous is questionable. ${ }^{130}$ Indeed, a great deal hinges on it. Under Allan J's finding that the lessees were not substantially incapable of performing, while the lessees would have been able to recoup the moneys owed to them by the lessor, ${ }^{131}$ they would not have been entitled to the significant damages they received. ${ }^{132}$ Given the lessees' ability to pay hinged on Mr Ingram's sister, the finding that the lessees were not substantially incapable seems most appropriate. It seems unlikely on the evidence that the higher "but for" standard could be satisfied.

For completeness, it is important to discuss what the situation would have been if the lessees were "substantially incapable" or "wholly and finally disabled"133 at the time of the repudiation, that is, the facts were such that the lessees could not have raised the money. In this event the repudiation by the lessor would have been justified. ${ }^{134}$ If the lessor could prove that, but for the lessees' lack of readiness and willingness to perform, the lessor would have been ready and willing to perform, the lessor may have been able to sustain an action against the lessees for damages. On the facts of Ingram the lessor would likely have been able to show that it only re-entered the premises due to the lessees being unable to pay the rent, and thus would be able to sustain an action. ${ }^{135}$ However, if the

129 At [30]. It is clear the Court considered this position was consistent with what Allan J held. There was no indication that the Court was departing from the finding of fact in the High Court. Their belief that their conclusion was consistent with that in the High Court may have been contributed to by the dissenting judgment of Priestley $\mathbf{J}$ in the Court of Appeal. The Supreme Court stated that "Priestley $\mathbf{J}$ noted the evidence in the present case that, but for Patcroft's breach, Mr Ingram would have had recourse to a family loan to pay the rent." However, Priestley J does not discuss whether Allan J accepted this evidence, and this position is not strictly what Allan $\mathbf{J}$ found. Therefore, as is detailed further, the conclusion reached by the Supreme Court in this respect is questionable.

130 It is perhaps arguable that the Supreme Court was entitled to make this assumption, given the evidence of Mr Ingram was not effectively challenged, meaning the lessees discharged their onus of proof. However, ultimately the onus on the lessees is a probative one. In light of this it is suggested that on the facts the position taken by their Honours was the less tenable of the two available, and also had significant ramifications that could, and should, have been avoided in light of the uncertainty.

131 Allan J awarded the lessees $\$ 36,597.55$ for lift maintenance over payments, in addition to the $\$ 100,000$ damages. Awarding the lessees the lift maintenance over payments but not damages essentially puts the lessees back in the position they were in (or should have been in) before the breach or repudiation.

$132 \operatorname{Ingram}(H C)$, above $\mathrm{n}$, at [92].

133 Dawson and McLauchlan, above n 41, at 83.

134 At 83 .

135 There was some suggestion made by Priestley $\mathbf{J}$ in the Court of Appeal that the lessor's repudiation was a stand-alone repudiation, because it was not responding to a breach by the lessees. However, it is suggested 
lessor could not show this, for example because it justified its stand-alone repudiation on the basis of information subsequently discovered (thus failing the "but for" test), both parties, not being ready and willing to perform, would be discharged from the contract, but neither could sue. ${ }^{136}$ Thus, while the lessor may use subsequent information to justify the repudiation, it would not then be able to sustain an action for damages.

\section{THE CONTRACTUAL REMEDIES ACT 1979}

The CRA aimed to "rationalize and simplify"137 the law relating to misrepresentation and breach of contract. ${ }^{138}$ Section 7 , concerning the right to cancel, was designed to codify "the existing rules both at law and in equity governing discharge for breach and repudiation", ${ }^{139}$ and to "provide a new starting point". ${ }^{140}$ However, the operation of the CRA as a code was, and is, subject to theoretical difficulties. Because the CRA retains the concepts of repudiation and breach without defining them, it is unworkable without reference to the common law. ${ }^{141}$ These concepts "can only be understood against their common law background". ${ }^{142}$ This point is forcefully put by Dawson and McLauchlan: ${ }^{143}$

The difficulties that confront us here reveal one of the central weaknesses in the thinking behind the Act. It is simply not possible to say on one hand "we abolish the common law rules as to discharge for breach", and on the other hand "we retain the common law concepts of repudiation and breach" - for the latter are integrally related to, and built up around, the common law rules.

that in the event the lessees were wholly and finally disabled the conduct of the lessor would be viewed as responding to the lessees' situation, despite the fact they re-entered the premises a day early.

136 No causal nexus exists between the repudiation and the other party's action or stance in these cases. Thus, a party providing a subsequent justification will avoid liability, but not be able to claim damages. The leading common law cases in this area concerned situations where defendants offered subsequent justifications in order to defend themselves against plaintiffs' claims. See Cowan v Milbourn (1867) LR 2 Ex 230; Pearce v Stevens (1904) 24 NZLR 357 (CA) and Fairbanks, Lavender and Son v Low Bros (1893) 12 NZLR 302 (SC). See generally Dawson and McLauchlan, above $\mathrm{n} 41$, at 81-85. See also Thompson v Vincent [2001] 3 NZLR 355 (CA) which held that the common law rule that a repudiation for inadequate reasons could later be justified by adequate reasons survived the CRA.

137 DW McLauchlan "Contract Law Reform in New Zealand: the Contractual Remedies Act 1979" (1981) 1 OJLS 284 at 285 .

138 McLauchlan, above n 137, at 289.

139 Dawson and McLauchlan, above n 41, at 57.

140 At 83 . It is interesting to note that $\mathrm{s} 7$ is the only section in the CRA that contains a codification provision.

141 Dawson, above n 59, at 106; Dawson and McLauchlan, above n 41, at 83.

142 Dawson and McLauchlan, above n 41, at 83.

143 At 83 . 
Of course, as the authors recognise: ${ }^{144}$

Holding that many of the principles underlying discharge for breach at common law have survived the passing of the Act ... runs counter to the intention of Parliament which was that $\mathrm{s} 7$ provide a code.

Thus: ${ }^{145}$

An attempt to give meaning to [the codification provision] s 7(1) and to the words "repudiation" and

"breach" in the rest of s 7 raises very great (and perhaps insoluble) conceptual difficulties.

It is against this background that the question of whether the common law rules have survived the CRA must be assessed.

Several cases have addressed this question, and Burrows, Finn and Todd now treat the matter as settled. ${ }^{146}$ While s 7(1) "replaces the rules of common law and equity as to discharge for breach, and ... makes no express reference to any need for readiness and willingness", 147 courts have held that the rules as to readiness and willingness survive the passing of the CRA. Hardie Boys $J$ in Chatfield $v$ Jones stated that a party "could not cancel unless they themselves remained ready and willing to complete". ${ }^{148}$ The Court of Appeal in Kriletich v Birnam Investments Ltd (Kriletich) was more hesitant, stating that there were: ${ }^{149}$

...differing views as to whether at common law a party may cancel a contract relying on the other party's breach, where the cancelling party is itself unwilling or unable to perform the contract ... and if not whether under the Contractual Remedies Act the same bar applies ...

However, Noble Investments, despite the hesitation in Kriletich, endorsed the series of cases that assumed: 150

...albeit with little discussion, that, despite the Contractual Remedies Act, a party must be ready, willing and able to proceed to completion in order to be able to validly cancel a contract.

Glazebrook J qualified this, stating the rule only applies where the party seeking to cancel would benefit from his or her own wrong. ${ }^{151}$ The Court in Ingram endorsed this view. ${ }^{152}$

144 At 85 .

145 Dawson and McLauchlan, above n 41, at 85.

146 John Burrows, Jeremy Finn and Stephen Todd Law of Contract in New Zealand (4th ed, LexisNexis, Wellington, 2012) at [18.3.3].

147 John Burrows, Jeremy Finn and Stephen Todd Law of Contract in New Zealand (3rd ed, LexisNexis, Wellington, 2007) at [18.3.3]

148 Chatfield $v$ Jones, above n 65, at 297.

149 Kriletich v Birnam Investments Ltd CA214/90, 27 February 1991 at 14.

150 Noble Investments Ltd, above n 49, at [44] and [45]. 
None of these cases discussed the theoretical issues that arise when importing common law concepts into an Act that purports to be a code. Nevertheless, in my view, the courts are correct in their general conclusion that the common law concept of readiness and willingness survives the introduction of the CRA. As Dawson notes, an important consequence of breach encompassing the other party being ready and willing to perform is that the "concept of readiness and willingness is already inherent in the Act, even though s 7(1) makes no express reference to it". 153

Given that readiness and willingness is inherent in the CRA, it is important to consider whether the line of cases dealing with waiver of conditions precedent also survives. These cases form an integral part of the rules surrounding readiness and willingness. Dawson and McLauchlan address this question. They note that while the waiver cases could be viewed as common law rules regarding discharge, ${ }^{154}$ because the repudiations are unaccepted it is difficult to view the contracts in these cases as at an end. Theoretically, the contract may still be performed, that is if the repudiation were withdrawn. ${ }^{155}$ They conclude that: ${ }^{156}$

It is therefore arguable that s 7(1) does not affect the waiver cases for they are not rules of the common

law governing the circumstances in which a party to a contract may treat it as discharged.

The waiver cases thus survive the CRA.

However, some waiver cases concern situations where there has been a purported cancellation or rescission for the "actual breach", ${ }^{157}$ making it easier to conceptualise the contract as discharged. Based on this the waiver cases could be seen as being removed by s 7(1). However, the purpose of the waiver cases is to allow an innocent party to bring a suit for actual breach. ${ }^{158}$ Any cancellation

151 Noble Investments Ltd, above n 49, at [47].

152 Ingram (SC), above $\mathrm{n}$ 2, at [40].

153 Dawson, above n 59, at 106.

154 At 80.

155 At 80 .

156 At 80 .

157 As opposed to an acceptance of the repudiation, thus the purported cancellation and/or rescission does not remove the issue of the unaccepted repudiation. See Foran $v$ Wight, above $\mathrm{n} 81$ where the purchasers rescinded the contract, and Ingram v Patcroft Properties Ltd, above n 2, where the Supreme Court held that the lessees cancelled by bringing the action against the lessor. In light of the unaccepted repudiation presenting a third choice, it was not necessary for their Honours to hold there was a cancellation. However, the fact that they did does not unhinge the analysis.

158 Dawson and McLauchlan, above n 41, at 76 and 77. See also Dawson, above n 57, at 27. 
allowed by the fact the waiver "creates" an actual breach is a by-product of the main purpose. ${ }^{159}$ For these reasons, and due to the inequitable outcomes that would likely occur if the waiver cases did not survive, it is suggested that it is permissible to use the waiver cases under the CRA. This dilemma highlights the tension between the CRA aiming to codify the common law by closely basing the statutory provisions on it, and the fact that the CRA "merely [attempts] to reproduce the basic common law rule without providing for ... the waiver line of cases". ${ }^{160}$ For this reason it is unlikely that this dilemma can ever be resolved in a way that is completely satisfying. However, the fact that the waiver cases survive the implementation of the CRA has "been accepted in several first instance judgments", ${ }^{161}$ and by the Court in Ingram.

\section{ISSUES ARISING IN INGRAM}

Regrettably, the Supreme Court in Ingram did not clearly apply the relevant common law principles. First, instead of considering Foran, the Court relied principally on the Privy Council's decision in Hirst (which upheld the judgment of the Court of Appeal, delivered by Blanchard J). Second, instead of clearly addressing the theoretical basis for the application of the common law principles under the CRA, their Honours were content to adopt the limited and vague analysis of the earlier authorities. Third, stemming from the failure to correctly pinpoint the issue in the case, the Court unnecessarily discussed Australian authority and classified the anticipatory breach cases as merely "lending support" to the view that the decision in the case could be squared with Asquith LJ's dictum. ${ }^{162}$ These cases actually address the very issue in question, and should have been the basis of the Court's discussion.

\section{$A$ Hirst v Vousden}

The primary issue in Hirst was whether, contrary to the lessors' contention, there was ever a contract between the lessors and the lessees. The respective courts held that there was a lease agreement. The secondary issue was then whether the lessors' purported cancellation for nonpayment of rent was valid. The Court of Appeal, upheld by the Privy Council, reasoned: ${ }^{163}$

159 The Supreme Court recognised this at [37] where they stated: "Equally, we would add ... [a party must be able to terminate the contract for actual breach] ... despite not having performed its part, provided that it could show that its own non-performance was justified by the repudiation."

160 Dawson and McLauchlan, above n 41, at 79.

161 Dawson, above n 57, at 26. See also Innes v Ewing [1989] 1 NZLR 598 (HC); Post Haste Courier Ltd v Casey HC Invercargill CP83/89, 24 October 1989; Eunson v Yee HC Christchurch CP579/88, 10 September 1990.

162 Ingram (SC), above n 2, at [37].

163 Hirst $v$ Vousden (CA), above n 19, at [16]; Hirst v Vousden (PC), above n 19, at [15]-[16]. 
How can it be said that lessees are obliged to keep making rental payments pursuant to a contract... when the lessors are refusing to acknowledge the existence of the lease contract? And how can a purported cancellation of the lease on that ground be valid?

The lessees were thus entitled to damages. ${ }^{164}$

Neither judgment elaborates on this reasoning. It is thus unclear what principles the decision was based on. However, while the case does not appear to be decided strictly on the principles surrounding readiness and willingness, the outcome is consistent with those principles. The lessors could not cancel for breach as they were not ready and willing to perform when the rent was being withheld, meaning the lessees were not in breach. Their repudiation was clearly not justifiable on the basis that the lessees were disabled from performing or had renounced their obligations. ${ }^{165}$ The lessees had lodged funds with their solicitor to demonstrate their willingness and ability to pay. ${ }^{166}$ The lessees therefore could take an action for actual breach as they were plainly willing and able to perform the contract but for the lessors' repudiation. This would entitle the lessees to the damages they received.

The Privy Council decision did state that the Court of Appeal's conclusion was confirmed by the lessees' "willingness ... to pay any arrears found properly due", ${ }^{167}$ suggesting their Lordships may have recognised the outcome was consistent with the approach described. Regardless, Hirst seems to be very much a decision on its particular facts. In Hirst the lessors' position was much more contradictory than that of the lessor in Ingram. The lessors denied a contract existed. They did not merely make a mistake whilst attempting to exercise a contractual right. Further, the lessees in Hirst were in a much stronger position than the lessees in Ingram. There were no questions in Hirst about whether the lessees would have been able to pay. This perhaps explains why the courts were so brief in their analysis. The answer seemed obvious.

Of course, a fuller statement of the principles would have been useful and would have avoided the present speculation. ${ }^{168}$ Given that Hirst did not do this, the judgment should not have been the basis for the Court's decision. Their Honours should have focused on Foran and the clearer

164 Hirst v Vousden (CA), above n 19, at [35]-[47] (original emphasis).

165 Dawson and McLauchlan, above n 41, at 83.

166 Hirst $v$ Vousden $(P C)$, above n 19, at [16].

167 At [16].

168 It is perhaps notable also that Hirst did not address the CRA, further reducing its usefulness. Insofar as Hirst did deal with the CRA the discussion is somewhat misleading. Their Lordships, following discussion in the courts below, referred to the assessment of damages under s 9 of the CRA. Section 9 does not deal with damages. Instead, s 10 preserves the right to claim damages at common law. 
statements of first principle in that case. ${ }^{169}$ Further, the focus on Hirst concentrated the decision in Ingram on whether the lessor could cancel. This emphasis was misdirected. It meant their Honours missed the more nuanced factual elements of the lessees' claim, because the assumption was, as in Hirst, that if the lessor could not cancel, the lessees must succeed. Thus the vital issue, brushed over in light of the focus on Hirst, was whether the lessees would have been ready and willing to perform but for the repudiation, allowing them to sustain an action for actual breach.

\section{$B$ Treatment of the Common Law and the CRA}

When importing the common law into the framework of the CRA the Court endorsed the following view: ${ }^{170}$

... the Court of Appeal in Noble Investments was of the opinion that the purpose of the common law rule requiring that a cancelling party be ready and willing to perform the contract in all material respects was to ensure that the party in question could not benefit from its own wrong. The Court said, in a judgment delivered by Glazebrook $\mathrm{J}$, that the rule survived the passage of the Act but did not apply where the cancelling party did not so benefit ...

This statement is problematic in several respects. First, it simplifies the complex common law rules down into a single statement: "at common law a party who wished to cancel had first to be ready and willing to perform the contract." 171 This is consistent with the earlier authorities, in particular Chatfield $v$ Jones which made an identical statement. However it is a vast oversimplification of the true position at common law. Dawson, discussing the statement made in Chatfield $v$ Jones, states that it "is clearly wrong"172 to suggest "that a contracting party must be ready and willing to perform before that party becomes entitled to cancel the contract" 173 because: ${ }^{174}$

The true position at common law was that a party could treat itself as discharged on the ground of the other party's failure to perform, notwithstanding that it had failed to perform its part.

Further, the focus on cancellation is misleading. The common law rules concern the ability to put a contract into suit, for which readiness and willingness to perform is a condition precedent. The

169 Regrettably, Foran, unlike Hirst, does not appear to have been raised in argument by counsel, which perhaps goes some way to explaining its notable absence.

170 Ingram (SC), above $\mathrm{n}$, at [40].

171 At [23].

172 Dawson, above n 59, at 104.

173 At 104. This position is perhaps understandable on the basis that in order to cancel for breach there must be a breach, meaning the cancelling party must be ready and willing to perform. However, this does not detract from the criticisms levelled at it.

174 At 105. 
simplification above does not identify the possibility of a waiver of the condition precedent. The authorities appear to have at least recognised this limitation, and have tried to address it by stating that the rule does not apply if the cancelling party does not benefit from his or her own wrong. In Ingram the Court accepted this statement of the law without hesitation. However, it is unclear where such a vague qualification comes from. Glazebrook J provided no cases to support it. The Supreme Court's endorsement of this position leaves the law in a troubled state.

Moreover, the examples of when a cancelling party benefits from his or her own wrong also pose difficulties. One example given was that the cancelling party benefited from his or her own wrong if he or she sought "to deprive the other party of the benefit of the contract in circumstances where the other party's breach is a direct result of breach committed by the [cancelling party]". ${ }^{175}$ This appears to equate breach with non-performance and, insofar as it does so, is misleading. ${ }^{176}$

Thus, instead of clearly discussing the principles in Foran, the Court has adopted a confusing rule that does not accurately reflect the common law. Further, their Honours accepted a vague and unsubstantiated qualification that could prove troublesome not only in its application by the courts, but for parties determining whether they are entitled to cancel. ${ }^{177}$

It is further concerning that, in line with earlier authority, the Court did not discuss the theoretical issues concerning the survival of the common law rules after the CRA. Their Honours were content to say that Noble Investments settled the question, as stated by Burrows, Finn and Todd, ${ }^{178}$ without grappling with the conflict between readiness and willingness being inherent in the concept of breach, and the CRA purporting to be a code.

The Court endorsed Dawson and McLauchlan's view that the waiver cases survive, ${ }^{179}$ but in doing so, both the waiver rule and the argument put forward by the authors were misunderstood. Their Honours stated: ${ }^{180}$

175 Ingram, above n 2, at [40].

176 The same difficulties arise with the other example given of when a cancelling party benefits from its own wrong. See Ingram, above n 2, at [40]. Other points in the judgment also appear to equate non-performance and breach. See Ingram, above n 2, at [1], [17] and [35].

177 The common law rules also concern the availability of damages. Under the simplification that the Supreme Court has adopted this aspect of the common law is neglected. The fact that the extent to which the parties would be able to perform was not taken into account in the remedy awarded in Ingram is a reflection of the overly simplistic approach. Thus the law surrounding the remedies available in these cases, and how these are to be determined, is also left uncertain.

178 Burrows, Finn and Todd, above n 146, at [18.3.3]; Ingram (SC), above n 2, at [40].

179 Ingram (SC), above n 2, at [39].

180 At [38]. 
As we understand it, this argument, which the authors favour, views waiver as excusing the [innocent] party's non-performance so that there is no breach by [the innocent] party of which the repudiating party may take advantage under s 7 ...

Strictly speaking, the waiver does not operate in that way. Given the "defaulting party"181 is not ready and willing to perform, the non-performance by the innocent party is not a breach. It does not need to be excused. Instead, the waiver means the defaulting party is in breach despite the innocent party not being ready and willing to perform. This allows the innocent party to put the contract into suit for actual breach. Thus, the reason the waiver cases survive is not because the repudiating party is unable to complain of the other's inaction. ${ }^{182}$ The authors state the waiver cases survive because these cases do not concern discharge for breach. ${ }^{183}$ The cases deal with situations where it is still theoretically possible to perform the contract, and allow the innocent party to put the contract into suit despite their non-performance. ${ }^{184}$ The confusion here stems from the misplaced focus in Ingram on the lessor's ability to cancel. ${ }^{185}$ In trying to understand the "waiver rule" against the background of whether the lessor could cancel the rule, and the reasons it survives the CRA, have been misconstrued.

\section{Use of Australian and Anticipatory Breach Cases}

After quoting three decisions of Australian State courts ${ }^{186}$ to align his conclusions "with the well-known dictum of Asquith LJ ..." 187 the Court stated that cases "on anticipatory breach also lend support to this view". ${ }^{188}$ With respect, this section of the judgment is poorly constructed. There was little need for the Court to have quoted snippets from multiple Australian authorities. The quoted segments are mainly used to support the proposition that the lessor could not cancel, which should not have been the main focus of the case. The extensive focus on this obscures the real issue, and importantly the Court's apparent endorsement of the third choice. ${ }^{189}$

181 At [38].

182 At [38].

183 Dawson and McLauchlan, above n 41, at 80.

184 At 77.

185 It is also suggested that the confusion regarding the operation of the waiver cases is what led to the conclusion that the waiver rule operated as an estoppel.

186 Ingram (SC), above $\mathrm{n} 2$, at [32]-[36].

187 At [31].

188 At [37].

189 Ingram (SC), above n 2, at [31]. 
It would have been much clearer to have simply discussed Foran and the other anticipatory breach cases. The reasons for this are twofold. First, these cases explicitly endorse the third choice. ${ }^{190}$ Second, the anticipatory breach cases do not merely "lend support" to the discussion in Ingram. They address the very issue in question - whether, at the date of performance the innocent party can bring an action for actual breach, despite not being ready and willing to perform. Both Foran and Peter Turnbull and Co Pty Ltd v Mundus Trading Co (Australasia) Pty Ltd ${ }^{191}$ dealt with situations where there was an anticipatory breach, and the issue was whether an action could be brought for actual breach at the date of performance.

In the light of this, the judgment would have been more readily comprehended if it were set out in reverse. As set out, the judgment first considers the case of Hirst, next how the conclusions square with Asquith LJ's dictum, and then moves to the anticipatory breach cases and s 7(1) of the CRA. A more logical approach would have been to address the anticipatory breach cases, including Foran, and then s 7(1). A discussion of Hirst was unnecessary, as was the discussion of the Australian cases. ${ }^{192}$

\section{CURRENT POSITION}

The relevant principles can be summarised as follows. In order to succeed in an action for breach of contract the promisee must show it was ready and willing to perform at the time of performance. The promisor will only be in breach if the promisee was ready and willing to perform at this time. It will likely be implied that the promisee was so ready, requiring the promisor to put this in issue. Once the promisor has put readiness and willingness into issue the probative onus lies with the promisee, although in the absence of evidence to the contrary, this burden will be relatively easily discharged.

In cases involving an unaccepted repudiation, where the time for performance has arisen, and performance has not occurred, a third option is open to the promisee. Aside from cancelling or affirming the contract, the promisee may take an action for actual breach. In such cases, the unaccepted repudiation waives the condition precedent of readiness and willingness to perform at the time of performance.

However, the requirement that the promisee be able to show it was ready and willing to perform is not waived entirely. The promisee must show it was ready and willing to perform at the time of the repudiation. The available remedy depends on the extent to which this can be shown. In order to be entitled to damages, the promisee must show that but for the repudiation it would have been

190 Foran, above $\mathrm{n} 81$, at 438 per Brennan J and 465 per Gaudron J.

191 See Peter Turnbull and Co Pty Ltd v Mundus Trading Co (Australasia) Pty Ltd, above n 127.

192 As mentioned, much of the confusion here stemmed from the focus on the lessor's ability to cancel. 
ready and willing to perform at the time of performance. ${ }^{193}$ If the promisee can only show that it was not substantially incapable of performing at the time of the repudiation, ${ }^{194}$ it will be put back in the position it was in before the contract, or before the breach or repudiation (depending on whether there is an ongoing relationship), by being repaid any moneys it had paid by way of deposit, or any moneys it was owed, for example. Thus, there is an important distinction between the promisee being ready and willing but for the repudiation, and the promisee being not substantially incapable of performing. The latter is a lower standard than the "but for" test.

Further, if the promisee was wholly and finally disabled from performing at the time of the repudiation, the promisor's repudiation will be justified, whether or not that was the reason the promisor repudiated. ${ }^{195}$ This means the promisor can use subsequent information about the promisee's situation to justify its repudiation. In particular, this may shield the promisor from an action. ${ }^{196}$ Obviously, in such a situation the promisor will seek to adduce evidence in support of its claim that the promisee was wholly and finally disabled, however, ultimately it is for the promisee to prove that it was not wholly and finally disabled from performing, once the promisor has put this in issue.

Despite this, the promisor will only be able to sue the promisee for damages if it would have been ready and willing to perform but for the repudiation, non-performance, or other action of the promisee. It is unlikely the promisor will be able to show this where it is advancing a subsequent justification. Because the justification was one the promisor was not aware of at the time, it is disingenuous for the promisor to argue it would have otherwise been ready and willing to perform. Thus if the promisor merely seeks to later justify its own stand-alone action based on the promisee's inability, the promisor will not be able to sustain an action. Instead, both parties, not being ready and willing to perform, will be discharged, and neither can sue. This is consistent with the position at common law that a party may treat itself as discharged, regardless of its own readiness and willingness.

\section{CONCLUSION}

The decision in Ingram suffered from a lack of precision as to the issue. While the Court correctly identified that the issue concerned whether an unaccepted repudiation could have legal

193 This envisages some sort of causal nexus between the promisor's repudiation and the promisee's nonperformance.

194 Again, this involves a causal nexus in the sense that the reason the promisee did not perform, or continue to make preparations to do so, should be the unaccepted repudiation.

195 Where a promisee is wholly and finally disabled from performing at the time of the repudiation, it is unlikely this will be due to any action on the part of the promisor. However, if the promisor took an action that led to the promisee being wholly and finally disabled, the result may be different.

196 See the discussion of the leading common law cases, above n 136. 
effect, and was correct in concluding that it could, the failure to pinpoint the more precise issue meant that the reasoning was unconvincing and potentially misleading. Instead of focusing on the very real issue of whether the lessees were entitled to bring an action against the lessor for actual breach, despite their lack of readiness and willingness to perform at the time for performance, the emphasis was placed on whether the lessor could cancel. While this issue caused much confusion in the Court of Appeal, a clear exposition of the common law principles concerning discharge for breach would have revealed that this was really a non-issue.

Unfortunately, at times it appears that the Court was so focused on whether the lessor was able to cancel, that it was assumed that if the lessor was not able to cancel the lessees' claim would automatically succeed. The focus on Hirst instead of the fuller statements of principle in Foran exacerbated this problem, and the unnecessary discussion of the other Australian cases was a result of it. The concern with the lessor's claim thus led to many of the difficulties discussed in this article, including the lack of attention paid to the distinction between the lessee being not substantially incapable of performing and being ready and willing to perform but for the repudiation. The Court, going a step further than the finding of fact made by Allan J, assumed that the lessees would have been able to pay but for the repudiation. A great deal hinged on this assumption. It meant that the lessees gained significant damages, when on a proper application of the principles in Foran the lessees should only have been entitled to the moneys owed to them by the lessor. Thus, while the case was decided in favour of the correct party, the overall outcome and the reasoning behind it left a lot to be desired.

This article has attempted to fill in the gaps. In particular it has undertaken a discussion of the applicable common law principles, and discussed the theoretical difficulties that arise in applying these principles under the CRA, which purports to codify the common law. It has concluded that the principles of the common law as to readiness and willingness, including the all-important waiver cases survived the implementation of the CRA. The Court too, sought to take this approach. However, the judgment was clouded by loose terminology, unnecessary discussion, and a somewhat illogical structure. The resulting statement of the law is a confusing oversimplification of the common law position that is unlikely to aid the resolution of future cases, particularly if they are as factually nuanced as Ingram. 